\title{
静脈性大動脈撮影法について
}

\author{
$\begin{array}{llllll} & \text { 医 } & \text { 長 } & \text { 中立東京第一病院泌尿器科 } & \text { 野 } & \text { 巌 } \\ & \text { 員 } & \text { 広 } & \text { 川 } & \text { 勲 }\end{array}$
}

\section{A STUDY ON INTRAVENOUS AORTOGRAPHY}

\author{
Iwao Nakano and Isao Hirokawa \\ From the Urological Clinic of the First National Hospital of Tokyo
}

\begin{abstract}
We performed intravenous aortography in 26 patients and obtained desired results.
Arm-to-tongue circulation time was measured by means of the preliminary injection of choleretin into cubital vein. Simultaneous injection of small dosis of contrast medium was made for the purpose of detecting side reactions. A total of $100 \mathrm{cc}$ of 75 per cent Urokolin $\mathrm{M}$ was injected into both cubital veins by means of two fifty cc-syringes with 16 gauge needles. Serial films in one second time interval were taken utilizing Sanchez-Perez Automatic Seriograph Model 110 equipment.

The results were satisfactory with the majority of cases. Seven cases were reported in detail. No serious complication was encountered.

We believe that intravenous aortography has high clinical value in its simplicity and safety, nevertheless the picture obtained may be rather light in density.
\end{abstract}

1929年 Dos Santos によつて行われ経腰的大動脈撮 影法柱現在では腹部大動脈およびその主要枝ならびに腎 腫痬, 腎賈胞, 先天性奇形等各種疾患抢ょび腎の血管性疾 患の診断扢よび治療方針の決定のためにも，益々必要欠 くべからざるものとなつて來たが, 少数例ではあるが, 腰部大動脈を盲目的に穿刺するととから生ずる重篤な合 併症, ときにして死亡例 ${ }^{25)}$ さえも報告されている. 即ち 合併症の頻度は多いものでは, Larrson \& Palmlöv ${ }^{26)}$ 13.6\%, Mc Affe \& Willson ${ }^{28)}$ の14.63\%から,少ないも のでは Miller et $\mathrm{al}^{30)}$ の $\mathbf{2 . 8} \%$, Kincaid \& Davis ${ }^{23)}$ の $0.4 \%$ 等の報告があり, $\mathrm{Mc} \mathrm{Affe}^{27)}$ の301病院の報告 例13207 例の統計では 135例に重篤な合併症がみられ， うち37例が死亡している. 合併症としては大動脈穿刺部 に於ける動脈周囲出血を來したもの (Larson \& Palml$\ddot{O ̈}^{26)}$, Mc Affe \&Willson ${ }^{28)}$, Smith et $\mathrm{al}^{38)}$, Crawford et $\mathrm{al}^{10)}$ ), 麻瘦來したの (Antoni \& Lindgren ${ }^{3)}$, Boyarsky ${ }^{7)}, \mathrm{Mc}$ Cormick $^{29)}$, Abeshouse \& Tiongson ${ }^{1)}$. Baurys $^{4)}$, Evans ${ }^{11}$, Nelson ${ }^{31}$, Grossman \& Kirtley ${ }^{17)}$, Killin \& Foster ${ }^{22}$.) , 造影劑が上腸間膜動脈内に 注入 され血栓症を來して小腸壊死を來したもの (Wagner \& Price $^{49)}$, Sante ${ }^{36)}$, Fineby et $\mathrm{al}^{14)}$, Wilder \& Steich$\mathrm{en}^{51}$.), 腎動脈注入され腎不全を來したもの (Mc Affe $\&$ Willson ${ }^{28)}$, Crawford et $\mathrm{al}^{10)}$, Conger et al ${ }^{9}$, Josselson
\& Kaplan ${ }^{21)}$, Alwall et $\mathrm{al}^{2)}$, Tarazi et $\mathrm{al}^{48)}, \mathrm{Clark}^{8)}$, 膵蔵炎を來したもの $\left(\right.$ Robinson $\left.^{35)}\right)$, 乳麼胸在來したも の (Kincaid \& Davis $^{23)}$, 佐藤等 ${ }^{37)}$ ) 等の報告がある.

こうした危険性を除去するために二, 三の方法が考案 され，逆行性大動脈撮影法 ${ }^{18)}$ があるがかなり煩雜であ る.しかし1948年 Weens et $\mathrm{al}^{50)}$. によつて行われた静 脈性大動脈撮影法は上述の如き合併症はない上に, 更に 危険性も極めて少ない事から安心して施行しうる便宜が あり, 我ふもこの方法を試みて甚だ満足すべき結果を得 たので，ここに報告する次第である。

I 手技

（1）患者の体位抢よびレ線撮影裝置

患者は第 1 図汇示す如くレ線台上に背位とし，両手を 90 度開き支持台上飞置く・レ線管は臍部よりや〉上方に 中心を合せ，患者の下方は 1 秒間に 1 枚宛フイルムの 撮影可能な連続撮影装置 (Sanchez-Perez Automatic Seriograph Model 110) を使用した。

(2) 循環時間の測定

撮影飞先立ち腕一腎循環時間に相当する腕一舌循環時 間の測定を行つた。即ち Choleretin (大日本製薬) 5 cck Urokolin M 1 cc (造影劑 Urokolin M 飞対方る 感受性検查のため) を混じたものを肘静脈内に注射し, 注射し始めてから苦味を感ずる迄の時間を Stop-watch 
第 1 図撮影時の状態

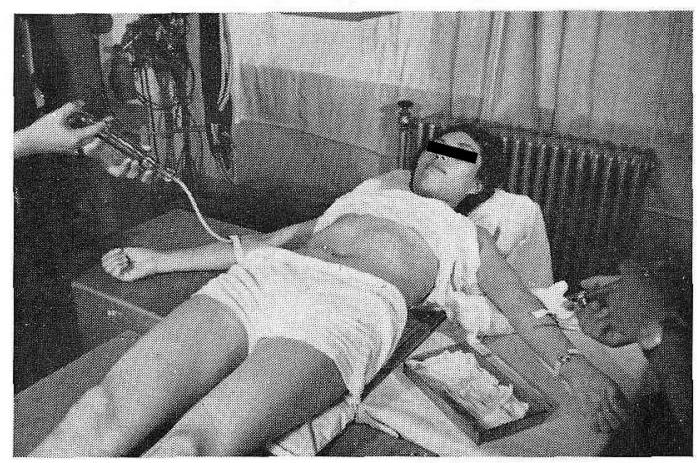

で正確に測定した。

（3）造影劑の注入去ょび連続レ線撮影

循環㭙間の測定招よび薬劑に詨する反応がない事孛碓 めた後撮影夺行つた, 注射器は我ふが考案したもので第
第 2 図 注射器

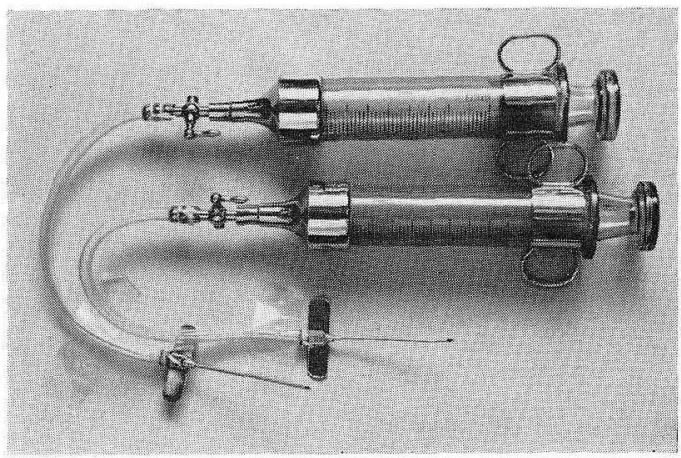

2 図に示古如く, 16 Gauge の翼状針のついた $50 \mathrm{cc} の$ Stop-cock Unit の注射器で, 武井医科光器製作所製のも の定使用した。造影劑としては75\% Urokolin-M (第一 製薬）起充たし，両側の肘静脈え出來る丈迅速に注入し

静脈性大動眽撮影症例

\begin{tabular}{|c|c|c|c|c|c|c|c|c|c|}
\hline No. & 病 & 名 & 性 & 年令 & 循滾時問 & 拄入恃問 & $\left|\begin{array}{lr}\text { 撮 } & \text { 影 } \\
\text { 開始洔間 }\end{array}\right|$ & $\begin{array}{l}\text { 撮影フイルル } \\
123456789\end{array}$ & 副作用 \\
\hline 1 & 筲 下 & 垂 & $\hat{0}$ & 43 & 18秒 & 6秒 & 6秒 & 000 & $(-)$ \\
\hline 2 & 特発性腎出 & & o & 22 & 10 & 4 & 8 & $0(0)$ & 塒麻疮 \\
\hline 3 & 高＼cjkstart血 & & q & 38 & 10 & 5 & 8 & $0(0)$ & $(-)$ \\
\hline 4 & 㑵 胱 腫 & & $\hat{0}$ & 42 & 12 & 6 & 6 & $0(0)$ & 頭 涌 \\
\hline 5 & 章 丸 腫 & & $\hat{\delta}$ & 65 & 13 & 4 & 4 & $0(0)$ & $(-)$ \\
\hline 6 & 左腎盂廆 & 瘍 & 우 & 70 & 13 & 5 & 7 & 0 (0) & $(-)$ \\
\hline 7 & 膀 胱 腫 & 瘍 & $\hat{0}$ & 50 & 12 & 6 & 6 & 000 & $(-)$ \\
\hline 8 & 高 血. & 压 & 우 & 52 & 11 & 6 & 6 & 000 & $(-)$ \\
\hline 9 & 水 䁂 & 症 & 1 & 18 & 12 & 5 & 8 & $0(0)$ & $(-)$ \\
\hline 10 & 筲 & 症 & 우 & 41 & 12 & 5 & 8 & 000 & $(-)$ \\
\hline 11 & 結核性膿腎 & & 우 & 52 & 13 & 6 & 6 & $0(0)$ & $(-)$ \\
\hline 12 & 水 腎 & 症 & 우 & 58 & 14 & 6 & 6 & 0 (0) & $(-)$ \\
\hline 13 & 馬 蹄 & 䟝 & $\delta$ & 39 & 13 & 5 & 5 & 000 & $(-)$ \\
\hline 14 & 腎結 & 核 & $\hat{0}$ & 34 & 13 & 6 & 9 & 0 (0) & $(-)$ \\
\hline 15 & 水 腎 & 症 & $\hat{0}$ & 26 & 12 & 5 & 8 & $0(0)$ & 蓴麻疮 \\
\hline 16 & 高血 & 圧 & 우 & 38 & 12 & 6 & 9 & $0(0)$ & $(-)$ \\
\hline 17 & 水 腎 & 症 & o & 28 & 13 & 5 & 7 & 000 & $(-)$ \\
\hline 18 & 副腎腫暢 & 疑 & $\hat{0}$ & 20 & 13 & 6 & 6 & 000 & $(-)$ \\
\hline 19 & アルドステロ & ン症 & $\hat{0}$ & 32 & 14 & 6 & 6 & 0 (0) & $(-)$ \\
\hline 20 & 腎結 & 不 & 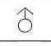 & 53 & 14 & 6 & 6 & 000 & $(-)$ \\
\hline 21 & 高 血 & 压 & $\hat{0}$ & 38 & 12 & 6 & 8 & $0(0)$ & 瞢庥疹 \\
\hline 22 & 水 腎 & 症 & $\hat{\delta}$ & 22 & 13 & 5 & 5 & $0(0)$ & $(-)$ \\
\hline 23 & 婜腫 & 瘍 & 우 & 54 & 13 & 5 & 5 & $0(0)$ & $(-)$ \\
\hline 24 & 趈転異常 & & $\hat{\delta}$ & 35 & 15 & 6 & 6 & 0 (0) & $(-)$ \\
\hline 25 & 腎 孟 腫 & 瘍 & 우 & 30 & 14 & 5 & 5 & $0(0)$ & 蕁麻疮 \\
\hline 26 & 腎性高血 & & 우 & 31 & 23 & 6 & 14 & 1000 & $(-)$ \\
\hline
\end{tabular}

表で撮影開始時間は造影剤注大侍よりの㭙間を示し, 撮影フイルムの○印は現像良妖のフイ ルムを，(○は影像が最为良好なフイルムの番号を示す。 
た. レ線撮影治注入終了直後或㳊循環時間の測定結果各 ら多少延長して開始し，1秒間 1 枚鴙の割合で10枚撮影 した。撮影条件な電压 $76 \mathrm{KV} ， 200 \mathrm{~mA}$ ，撮影時間な0.1 秒である。

\section{II 結 果}

我々の試みた静脈性大動脈撮影の症例纱第1羡《示す 如々26例である.症例の最年少者は18才，最高命者は70 才迄々施行したが，全例に造影劑注入直後全身火枃熟感

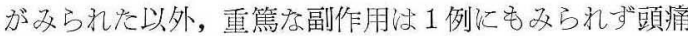

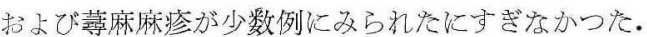

循環㭙間け10 18秒，平均12.8秒（18秒及び23秒の2 例岚除く）で，患者に上り反応の遅い者がある故に，と の様な場合は繰辺し検查实行了必要がある事な云う迄も ない. 連続撮影フイルムと循環時間との関係定みるこ， 表に多られる如く多少のずれは存在するが，循環時間と 撮影明膫なレ線フイルムとの間に注大凡一致するといら 結果が得られた。次に代表的な症例の大動脈撮影像を示 すと.

[症例]内藤某，22才の女子.

特発性腎出血の症例で, 大動脈像は第3 図に放ら机る 如く，在右の腎動脈等が全く異常なく描出され，正常の 動脈分布像が得られた。

[症例 6 ]磯谷某，69才の女子.

病名：左腎跙腫煬.

後腹膜乘体撮影扔よび逆行性腎盂撮影では第 4 図《示

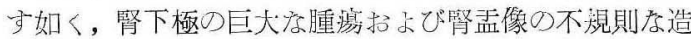

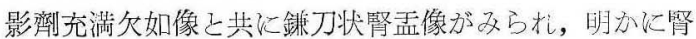

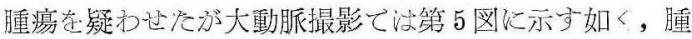
瘍の部分に活血管分布招よび造影劑の唄留像はなく，連 続撮影のネフログラムでもとの溙な所見心得られなかつ

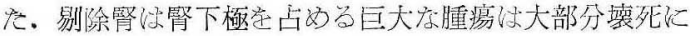
陌つた腎需瘍であつた。

[症例]小林某，52才の反子.

病名：右結核性膿腎症.

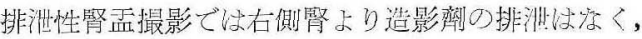

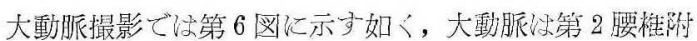

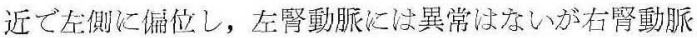

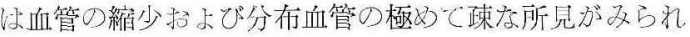
在.

[症例12]川島某，58才の女子。

病名: 右水腎症.

逆行性腎㙉撮影では前後像の第 7 龱招よび側位像の第 8 园に示す如く，右筒孟尿管移行部の屈曲亡共に右水腎 症の所見があり，大動脈撮影では第 9 図に久られる如く
第 4 腰椎附近の大動脈より右腎下極に入る異常血管が認 められ，手術時にもとの所罗が碓認され尿管成形于術定 行い経過洒めて順調である。

〔症例23】斉藤某，54才の女子.

病名 : 右腎腫瘍

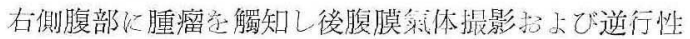
腎孟撮影で心第10図にみられる如く，右婜盖の桩張，右 腎盂下極の前後生迫像执子び尿管の左方止迫像㤂 る れ，大動脈撮影でほ第11図に文られる如く，睡瘤に相当 吉る部分で夫動脈が左方に偏位しこの部分には定型的な

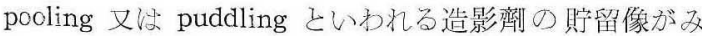
られ，連続撮影では時間の経過と共に造影劑の實留所見 が一瘴明瞭となつた。本症例の剔除腎は Grawitz 腫瘍 であつた。

〔症例25】川时某，30于の女子.

病名 : 左筒盂腫瘍

左側腹部の疼痛で來院. 後腹膜奥体撮影括よび逆行性 腎孟撮影では第12図にみられる如く，腎需为に腫瘍の存 在告示陰影欠損があり，大動脈撮影では第13図に文ら れる如く第 3 腰椎附近の大動脈より左腎下極に入る異常

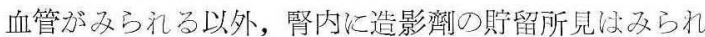
9゙剔除腎では腎盂腫瘍であつた。

〔症例26】板食某，31才の女子.

病名：腎性䯩血圧

最高血圧 210～230，最低血圧 120～130という高血 圧がある。排泄性腎需撮影で灶第14図に夕られる如く右 腎孟像は左軣盂像に比して薄く，大動脈撮影では第15図

第 3 図症例 2

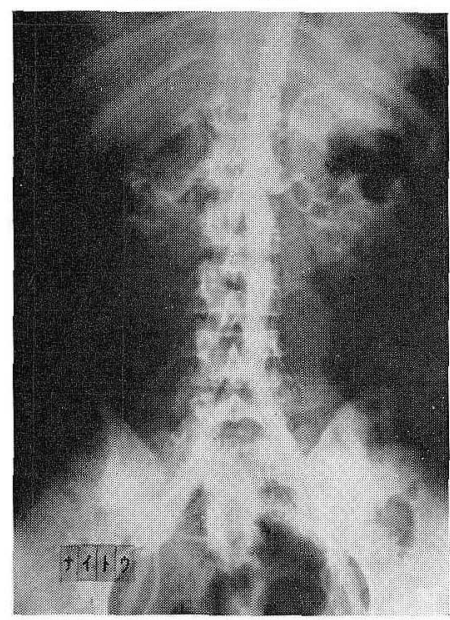

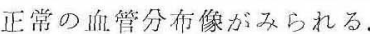


第 4 図症例 6 ：左腎孟尰序

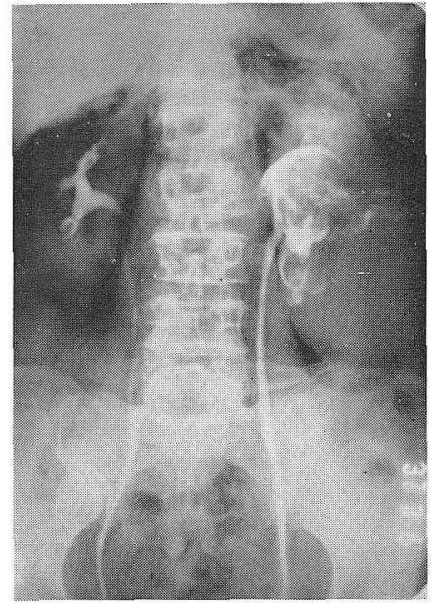

左腎下極の巨大腫瘍，造影威の充满欠如像打よび鎌为 状腎㙉像がみられる。

第 6 図 症例 6 : 右結核性膿腎症

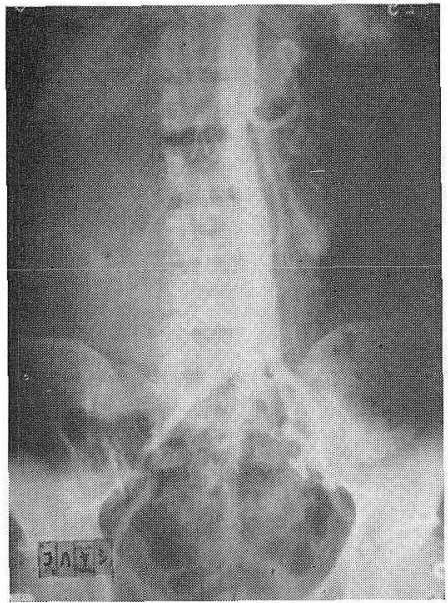

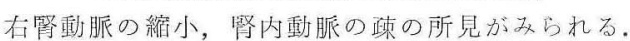

第 8 図症例12：右水腎症

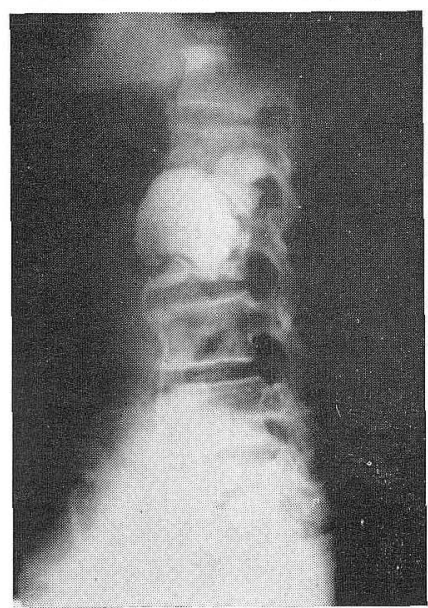

逆行性腎寻撮影の側位像では右腎孟尿管移行部の同亚 と共に右水腎症の所見がみられる。
第 5 図症例 6 ：左腎盂腄痬

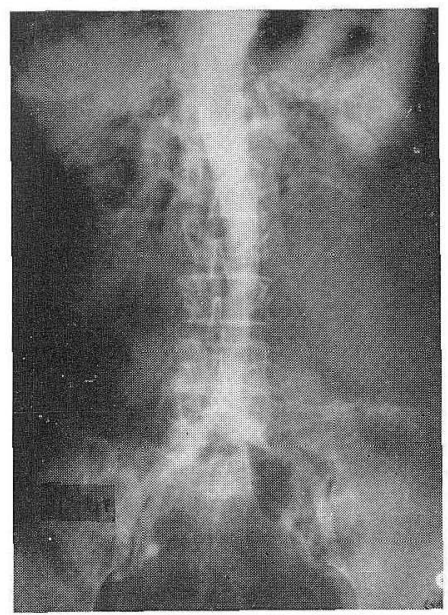

左㛑嗹瘍の部分には造影剤の貯留像はない。

第 7 図 症例 $12:$ 右水腎症

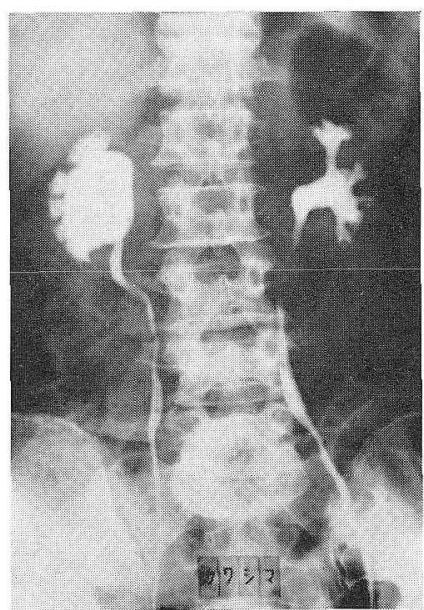

逝行州:腎系撮影の前後像では右水腎症の所見がみられ る。

第 9 図症例 12 : 右水腎症

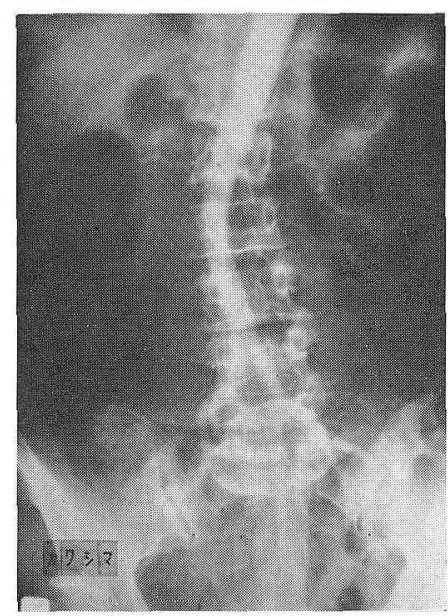

右腎下極に入る罢常血管がみられる。 
第10図症例 23 : 右腎腫瘍

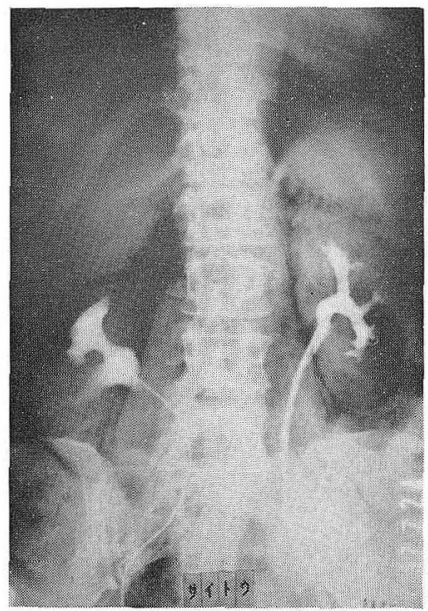

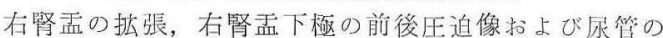
左方生迫像がみられる。

第12図症例 $25:$ 左腎盘腫瘍

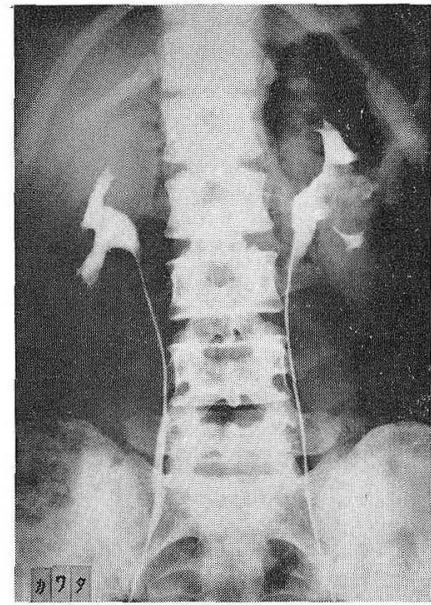

左警血内には陰影欠損がられる。

第14図 症例26：腎性高血圧

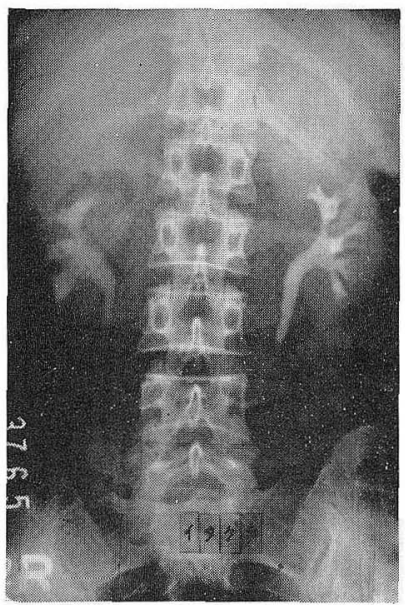

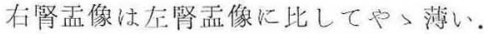

第11図．症例23：右腎盘腫瘍

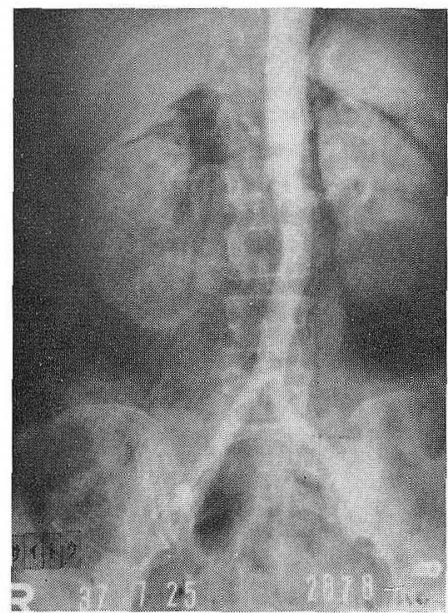

大動脈の左方偏位と共に腫瘤に相当する部位で造影剂 の町留像がみられる。

第13図 症例 25 : 左腎孟尰瘍

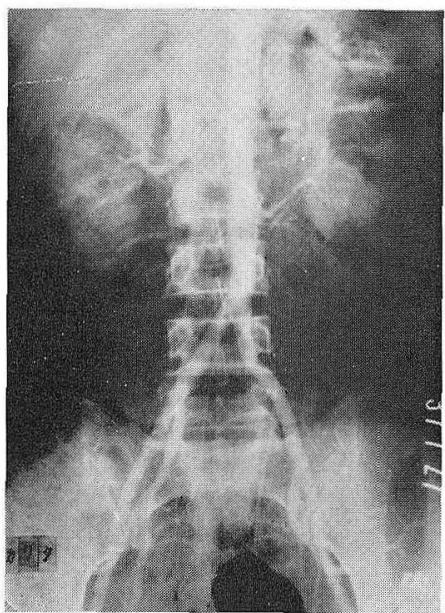

左腎下極に大る暴常血管がみられる以外に腎内に造影 郕の䝪留所見はみられない。

第15図 症例 26 : 腎性高血庄

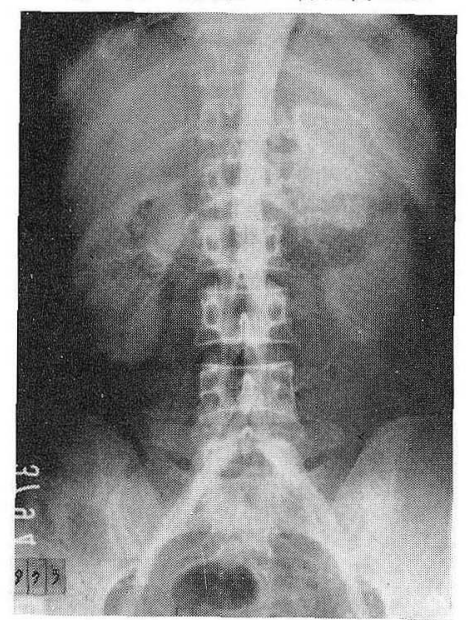

右腎動脈の狭䆓がみられる。 
にみられる如く吕督動脈の狭窄が認められた。

III 考按

静脈性大動脈撮影は静脈性心臓血管撮影の原理 ${ }^{33}$ ) 34339) 41142)を応用したすので，1948年 Weens et $\mathrm{al}{ }^{500}$.が70\% Urokon 50ccの急速な静脈内注入後に良好なネフログ ラム時として大動脈像が 描出される事を示したのが最 初で, 1954年に Evans et $\mathrm{al}^{122}$ ・は20例のネフロトモグ ラムのうち 12 例飞大動脈像打よび腎血管像がみられたと 報告し, 1958年には Bernstein et $\mathrm{al}^{5)}$, 飞より又1958年 には Steinberg et $\mathrm{a}^{142}$. によつて安全な静脈性大動脈 撮影法の手技について報告があつて以來, Steinberg et a|(43) 44) 45) 47) の各種疾患について行つた詳細な報告や更 飞 Harris et al ${ }^{19}$, Zerbi-Ortiz \& Weldon ${ }^{52)}$, Bosnick \& $\mathrm{Byck}^{6)}$ の報告もあり, 今日では安全にして確実な方 法として推奖されている.

本邦では稲田等 ${ }^{20)}$, 後藤等 ${ }^{15) 16)}$, 大谷 ${ }^{32}$ の報告がある.

(1) 撮影方法について

本撮影法で最も肝要な点は静脈内に注入された造影剤 が心循環を経て何秒後に腹部大動脈達するかを知る事 で, Steinberg et $\mathrm{al}^{42)(6) \text { 47) }}$ Harris et al ${ }^{19)}$ は Sodium Dehydrocholate(Decholin)を肘静脈内に注入しロ中にに が味を感ずる迄の時間即ち腕から舌迄の循環時間 +0.5 秒を注射後腹部大動脈に達する時間として, 撮影開始時 間の指標としている. Bernstein et $\mathrm{al}^{5)}$ 仙 $\mathrm{I}^{131}$ labeled Renografin 25〜50 $\mu$ c 食塩水と混じたものを注射し, Esterline-Angus Recorder で放射能を記録して 撮影開 始時間学知り更に連綂撮影裝置を使用している. 我々は Choleretin 使用して腕一舌循環時間を 測定し,これ を肘静脈一大動脈間の循環時間の指標己し循環時間と連 続撮影とが適当に一致する様㵊影を試みた所, 最良の レ線フイルムと循環時間との間には略一致すするという 結果が得られた。連続裝置を使用する場合は大凡の循環 時間を知る文で充分であるが，一層正確な循環時間を知 るには Radioisotope を使用するのが最も適切であると 考えられる。

次に造影剂は出來るだけ急速に注入する事が大切で, このためには出來るだけ太い注射針安使用し, 適当な静 脈の久如している場合には注射針挿入のため静脈切開を 行う必要がある. 本邦の後藤等 ${ }^{15) 16}$ 泣造影㓣を一側肘静 脈より急速注入する方法を使用しているが，乙れは反 対側腕頭静脈からの血液により造影剂が稀釈される恐れ がある故に，現在では両側よりの注入法が行われて扔 り我々もとの方法を用いた。 注入に際しては腕を上昇
させ，肩関節注緩かにして第 1 肋骨下で鎖骨下静脈が圧 迫されない様に注意し, 注入時沁吸鸦運動安行わせる 事等によつて Steinberg et $\mathrm{al}^{422(4) \text { (7) }}$ は $1 \sim 1.5 \sim 2.0$ 秒以内に多量の高濃度の造影訪を注入している。造影郕 としては高濃度のものの使用が望ましく外国では85〜90 〜 95\%の Hy paque が使用され，我々は75\% Urokolin $\mathrm{M}$ 定使用した。造影剂の量注 Steinberg et $\mathrm{al}^{42)}$ は各腕

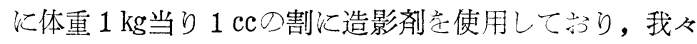
恃各腕に50cc宛使用した。急速注入方台ため汇造影 剂の粘稠度も関係するもので, 粘稠性が低〉しかも高濃 度の造影版が本撮影法に適している事峙云う迄もない。

（2）静脈性大動脈撮影法の利点と欠点について.

静脈性大動脈撮影法治経腰的大動脈撮影法汇比して次 の如き利点がある・即ち

（i）経腰的大動脈撮影の際に及ら㣗る盲目的穿刺 によつて生ずる腹腔内臓器, 脊随, 腎動脈, 上腸管膜動 脈㧍よび大動脈自身に対する障害老防止出來るとと.

（ii）大動脈の走行異常や腫瘤汇よる圧迫等のため に大動脈学刺出來ず，従つて実施不能という状態を來 すととがないとと。

（iii）急速な造影刻注入によつて生ずる高度の大動 脈圧を防止出來ること.

（iv）体位が腹臥位という不自然な位置でなく背位 であるとと.

(V) 麻醉が不要であるとと.

(VI) 経腰的大動脈撮影の際は穿刺が左側である故

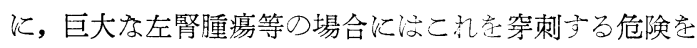
避けることが出來ること.

（III）経腰的大動脈撮影の場合に泣針先の位置に上 つて注入した造影㓮が一部偏在するととがあり，その ために或る血管には余計に入り，他の血管に波少なく入 る可能性があるが，静脈性大動脈撮影つ場合に结造影訪 が充分に血液と混合するためとの心配がなく，血管の自 然の分布状態を知るととが出來ると考えら沉るとと.

(VII) 本撮影法㴗部大動脈つ文ならす必要なら頭 部, 心臟血管系, 未稍血管等の描出も可能であること. 等を挙げることが出來る.

又逆行性大動脈撮影法に比しては血管内カテーテル挿 入が不要であること.手技が煩雜でないこと等が挙げら れ，何れにしろ従來の方法に比して操作が簡単であり， しかも安全であるこいう点では報告者の全てが認める所 である、特に最近腎性高血圧の診断法として大動脈撮影 法注必要久くべからざるものとなつて來たが，本撮影法 
は安全, 簡単しかも自然な状態で大動脈党描出する点か ら腎性高血圧の診断法の Screening test としても適切 な撮影法であると考えられる。

静脈性大動脈撮影法の唯一の欠点としては, 影像が鮮 明でないことでこの事は両側腕の静脈へ急速に多量に高 濃度の造影剂を注入するととによつて改善されたと流い え, これ注造影郕が稀釈されるためで避け得られ㰠欠点 と云えょう。また循環時間の著しく延長を來す様な心疾 患を有する場合も影像山得られないもので, Steinberg \& Marshall ${ }^{46)}$ 泣58秒の循環時間を有する心疾患例には 影像が得られなかつたが, これは造影剤のBolus が得 られなかつたためであると述べ, Haaris et $\mathrm{al}^{199}$. は循 環時間が15秒以上の場合は賀弱な影像しか得られないと している.

\section{（3）静脈性大動脈撮影施行時の危険性ついて}

静脈性大動脈撮影々際して々経腰的大動脈撮影の際の 大動脈穿刺による合併症は全て除去出來る譯であるが， 高濃度の造影用急速にしかも排洲性腎孟撮影時の5 倍 量を注入することによる造影剂の副作用による危険性泣 当然考虑しなければならない. Finby et $\mathrm{al}^{14)}$. は排泄性 腎孟撮影時に泣 $6 \sim 7$ 万例に 1 例の死亡例があつたと述 べ, Steinberg \& Marshall ${ }^{46)}$ 心蔵血管撮影を行つた 5000 例中 3 例の死亡例があつたと述べている.静脈性大 動脈撮影では Steinberg et $\mathrm{al}^{46) \text { 47) 40) }}$ 活 2 例の肺浮腫を 來して死亡し泛症例走報告している。我ふ法感受性検査 中呕吐を來して中止した 1 例以外には，4 例に薵麻疹, 1 例に頭痛が及られた湶か, まだ重篤な合併症を経験し ていないが，造影版江対する過敏症には充分な注意が必 要であり, 副作用の少ない造影剂の出現を期待するもの である. Steinberg \& Marshal1 ${ }^{16)}$ 注輕度な腎機能不全 に注禁忌ではないが重篤な尿毒症患者には本撮影法法試 みない万がょいこしておりり，我々も高度の腎機能障害患 者や全身状態の不良な患者には試みるべきではないと考 える次第でる。

以上静脈性大動脈撮影法について簡単に述べたが, 本 撮影法核動脈撮影法としては特にすぐれているという譯 ではなく，各疾患に応じて最も適切な撮影法を試みるべ きであるが，本撮影法法比較的客易に行い得る利点があ り一応核試みしてしかるべき方法であると云えよう。

\section{IV 結 語}

静脈性大動脈撮影法の術式を述べるとともに, 我々の 試みた症例について報告し, 併せて本撮影法につき考察 を加えてみ衣。
国立東京第一病院長市川篤二博士の御校閲を深謝致し ます。

当院放射線科桜木医長並びに科員一同の御協力を深謝 致します。

\section{文献}

1) Abeshouse, B.S. \& Tiongson, A.T.: J. Urol., 75. $348,1956$.

2) Alwall, N., Johansson, S., Tornberg., A., \& Werkö, L.: Acta chir. Scandinav., 109, 11, 1955.

3) Antoni, N., \& Lindgren, E.: Acta chir. Scandinav., 98, 230, 1949.

4) Baurys, W.: J. Urol., 75, 846, 1956.

5) Bernstein, E.F., Greenspan, R.H., \& Loken, M.K.: Surgery, 44, 529, 1958.

6) Bosnick, M.A. \& Byck, W.: Am. J. Roentgenol., \& Rad. Therapy, 84, 898, 1960.

7) Boyarsky, S.: J.A.M.A., 156, 599, 1954.

8) Clark, C.G.: Lancet, 1, 769, 1958.

9) Conger, K.B., Reardon, H. \& Arey, J.: Arch. Surg., 74, 287, 1957.

10) Crawford, E.S., Beall, A.C., Moyer, J.H. \& De Bakey, M.E.: Surg. Gynec. \& Obst., 104, 129, 1957.

11) Evans, A.T.: Am. J. Roentgenol., \& Rad. Therapy, 72, 574, 1954.

12) Evans, J.A., Dubilier, W., Jr. \& Monteith, J.C.: Am. J. Roentgenol., \& Rad. Therapy, 71, 213, 1954.

13) Fineberg, C., Schechter, D.C. \& Barrick, C. W.: J.A.M.A., 168, 1232, 1958.

14) Finby, N., Evans, J.A. \& Steinberg, I.: Radiology, 71, 15, 1958.

15) 後藤薰: 泌尿紀要, 8, 87, 1962.

16）後藤薰，他：泌尿紀要， $3,99,1957.4,392$, 1958.

17) Grossman, L.A. \& Kirtley, J.A.: J.A.M.A., 166, 1035, 1958.

18）市川篤二：日本泌尿器科全書, 第 1 巻, 350 , 金 原出版及び南江堂, 東京, 1961.

19) Harris, A.P., Allen, J.H. \& Porch, P.P.: J. Urol., 85, 377, 1961.

20）稲田務, 他：治療，37，714，1955.

21) Josselson, A.J. \& Kaplan, J.H.: J. Urol., 72, 256, 1954.

22) Killin, D.A. \& Foster, J.H.: Ann. Surg., $152: 211,1960$.

23) Kincaid, O.W. \& Davis, G.D.: New. England. J. Med., 259, 1017, 1958.

24）岸本孝, 他 : 日泌尿会誌, 52, 856, 1961.

25) Koszewski, B.J., Reedy, W.J. \& Iwerson, F. 
Ann. Int. Med., 48, 902, 1958.

26) Larson, H. \& Palmlöv, A.: Acta. radiol., 38, 111, 1952.

27) Mc Affe, J.G.: Radiology, 68, 825, 1957.

28) Mc Affe, J.G. \& Willson, J.K.: Am. J. Roentgenol., \& Rad. Therapy, 75, 956, 1956.

29) Mc Cormick, J.G.: J.A.M.A., 161, 860, 1956.

30) Miller, G.M., Mylie, E.J. \& Hinman, F., Jr.: Surgery, 35, 885, 1954.

31) Nelson, O.A.: J. Urol., 65, 911, 1951.

32）大谷幸郎：泌尿紀要, 6, 1019， 1960.

33) Robb, G.P. \& Steinberg, I.: Am. J. Roentgenol., \& Rad. Therapy, 41, 1, 1939.

34) Robb, G.P. \& Steinberg, I.: J.A.M.A., 114, 474, 1940.

35) Robinson, A.S.: Arch. Surg., 72, 290, 1956.

36) Sante, L.R.: Radiology., 56, 183, 1951.

37）佐藤昭太郎他：臨床皮泌，15，651，1961.

38) Smith, P.G., Evans, A.T., Elsey, E.C. \& Felson, B.: Am. J. Roentgenol., \& Rad. Therapy, 67, 183, 1952.

39) Steinberg, I.: Am. J. Roentgenol., \& Rad. Therapy, 81, 886, 1959 .

40) Steinberg, I.: Circulation., 23, 534, 1961.
41) Steinberg, I., \& Finby, N.: Arch. Surg., 74, 29, 1957.

42) Steinberg, I., Finby, N. \& Evans, J.A.: Am. J. Roentgenol., \& Rad. Therapy, 82, 758, 1959.

43) Steinberg, I., Finby, N. \& Evans, J.A.: Am. J. Roentgenol., \& Rad. Therapy, 86, 1108, 1961.

44) Steinberg, I. \& Karl, R.C.: Am. J. Roentgenol., \& Rad. Teerapy, 82, 902, 1960.

45) Steinberg, I. \& Lord, J.W.: J.A.M.A., 174, $74,1960$.

46) Steinberg, I. \& Marshall, V.F.: J. Urol., 84, $456,1961$.

47) Steinberg, I. \& Moore, S.W.: J.A.M.A., 175, 446, 1961.

48) Tarazi, A.K., Margolis, G. \& Grimson, K.S.: Arch. Surg., 72, 38, 1956.

49) Wagner, F.B. \& Price, A.H.: Surgery, 27, 621, 1950.

50) Weens, H.S., Olnik, H.M., James, D.F. \& Warren, J.V.: Am. J. Med., 5, 620, 1948.

51) Wilder, R.J. \& Steichen, F.M.: Arch. Surg., 80, 198, 1960.

52) Zerbi-Ortiz, A. \& Weldon, W.V.: New. England. J. Med., 264, 19, 1961. 